\title{
Køn, krop og ånd i middelalderen
}

Af Else Marie Wiberg pedersen

Hvordan opfattede man fanomenerne køn, krop og and i middelalderens åndelige miljoer?

Cistersienserne brugte et rigt og nuanceret billedsprog, der ikke kan forstios i snavre dualismer men transcendever traditionelle kønsopfattelser.

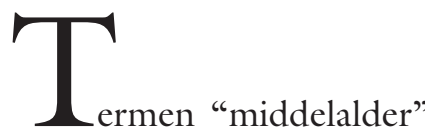

dækker over lige så mange forskellige tidsspand og temafokuseringer, som der er middelalderforskere. Geografisk er der ikke så megen tvivl. Med "middelalder" tænker man på den vesteuropæiske civilisations område. I en protestantisk kulturel og teologisk sammenhæng tænker de allerfleste på de såkaldt store teologisk-filosofiske tænkere som et positivt udtryk for "middelalderen"; og på krige, sygdomme og streng askese som udtryk for åndløs mørke mellem antikken og renæssancen. ${ }^{1}$ Men siden 1970'erne er middelalderen, især perioden ca. 1000 - 1400- tallet, i stigende grad blevet rehabiliteret som det stik modsatte, nemlig en kulturelt blomstrende og åndrig tid. Termen problematiseres da også stadig mere, blandt andre har den danske professor i kirkehistorie J. Balling gjort endeligt op med den uheldige konstruktion "middelalder" og i stedet valgt at tale om perioden fra 700 -tallet til 1700-tallet (termens 
oprindelse) som “det gamle Europa", der leder op til vor tid (Balling 1986 og 1991).

I takt med at den almene historieforskning har rehabiliteret det gammeleuropæiske åndsliv, har ikke mindst kvinde- og kønsforskningen udvidet perspektivet i udforskningen af dette åndsliv. Med sin bestræbelse på at forske i og skrive de glemte og oversete historier af og om kvinder, har man kastet nyt lys over livet i det gamle Europa.

I rækken af dem, der har bidraget til en perspektivudvidelse af det gammeleuropæiske åndsliv, bør den norske idéhistoriker Kari Børresen og den amerikanske mentalitetshistoriker Caroline Walker Bynum fremhæves. Disse to forskere har siden begyndelsen af 1980'erne været med til at sætte dagsordenen for udforskningen af og debatten om kvinder og køn i middelalderen. For Kari Børresens vedkommende skete gennembruddet med den amerikanske udgivelse i 1981 af hendes doktordisputats Subordination et équivalence, som var blandt de første kønshistoriske studier. For Caroline Bynum var gennembruddet hendes bog Jesus as Mother. Studies in the Spirituality of the High Middle Ages, som var blandt de første, der fremlagde mentalitetshistoriske studier af primærtekster, hovedsageligt fra cisterciensertraditionen. Begge har været til stor inspiration for mange.

Selv kan jeg takke disse to kønsforskeres bidrag for et engagement i den gammeleuropæiske teologi og kvinders placering i den gammeleuropxiske kirke. Men jeg kan ikke siges at tilhøre nogen bestemt feministisk skole. Min metode er den at læse kildematerialet tekstnært uden fastlagte og bastante teorier. Skønt jeg er mig bevidst, at man aldrig læser forudsætningsløst, så håber jeg på denne måde at læse så fordomsfrit som muligt: at læse, hvad der står $i$ teksten. Jeg kalder det at læse forlens $\mathrm{i}$ modsætning til den baglæns læsning, der med en for rigid, bestemt metode let kommer til at læse noget ind $i$ teksten. Først når jeg har læst den enkelte tekst, sætter jeg den ind i dens kontekst (historie, tradition) for til sidst at læse den intertekstuelt (i relation til andre tekster). Det, jeg som teolog analyserer, er i sagens natur, den teologi, der kommer til udtryk i teksten, og på hvilken måde den kommer til udtryk.

I det følgende vil jeg koncentrere mig om at afdrkke synet på køn, krop og ånd $\mathrm{i}$ cisterciensertraditionens teologi. Cisteciensertraditionen var den populæreste og mest indflydelsesrige $\mathrm{i}$ det 12. og 13. århundredes Europa, og den udmærker sig i denne sammenhæng ved at have leveret et stort tekstmateriale med nogle af den tids mest billedmættede tekster.

Artiklen vil tage udgangspunkt i traditionens åndelige fader Bernhard af Clairvaux (1090 - 1153), hvis syn på kvinder præsenteres på baggrund af hans lære om jomfrumoderen Maria, især i relation til Eva-Maria-typologien, og hans breve til forskellige kvinder. Dernæst behandles synet på kvindelighed, krop og and hos tre nonner fra 1200-tallet, med tilknytning til cistercienserne. Det drejer sig om Beatrice af Nazareth (1200-1268), Mechtild af Hackeborn (1241-1298) og Gertrud af Helfta (1256$1302)$.

Det er mit mål at vise, at det gammeleuropæiske syn på krop og køn ikke alene ikke kan fremstilles som entydigt negativt, som mange har gjort det. Man kan heller ikke nøjes med at fremstille det som den tvetydighed, der afspejles i det ideelle plans dikotomi i den velkendte Eva-Maria-typologi, hvor den almindelige kvindelighed forbindes med kropslighed og ond-skab, mens jomfrumoderen, der har absolveret sit køn, forbindes med det ukødelige og fuldkomne. Faktisk må man bevæge sig til den flertydighed, som karakteriserer i hvert fald cisterciensernes tekster, for at yde det krops- og kvindesyn, vi møder hos dem retfærdighed. Cisterciensernes flertydige syn på køn og krop kan tilskrives det faktum, at man oscillerer mellem det ideelle og det reelle plan, idet man ganske vist kan operere med idéplanets stereotyper men ofte vil la- 
de dem glide ind i uventede sammenhænge og bruge dem ganske atypisk. Nok kan kvindelighed og kødets skrøbelighed undertiden ses som forbundne størrelser, men de er ikke nødvendigvis bundet til et bestemt køn. Dertil kommer det forhold, at cistercienserne udtrykker sig i et veludviklet og sublimt symbolsprog, der netop gør det muligt at sprænge de grænser, som typiseringens sprog sætter.

\section{Bernhard af Clairvaux.}

Bernhard af Clairvaux var én af sin tids mest indflydelsesrige mænd. Han satte sit præg på både åndslivet og det politiske liv i første halvdel af 1100-tallet, og det var under hans ledelse, den nye reformklosterbevægelse cistercienserne oplevede en hastig vækst, ${ }^{2}$ efter at han som 20 -årig ung ridder sluttede sig til den.

Trods sin store indflydelse på samtidens politik er Bernhard især kendt for at være mariolat, dvs. en stor beundrer af jomfru Maria, selvom hans skrifter til Maria (hovedsageligt sermoner til diverse mariafester) kun udgør 2\% af hans samlede produktion (Barré 1953). På denne måde fremstår Bernhard egentlig som en overordentlig stor ynder af kvindekønnet. Men samtidig er han af nogle forskere blevet fremhævet som særdeles misogyn. ${ }^{3}$ Man kan dog ikke med et hastigt pennestrøg blot karakterisere Bernhard som det ene eller det andet. For det første er hans forfatterskab meget vidtspændende og omstridt, idet der ofte er tale om "lejlighedsskrifter" af forskellig karakter (spændende over såvel traktater, som sermoner og breve). For det andet er skrifterne så indsvøbt i symbolsprog, at man ikke blot kan historisere enkeltudsagn, men må læse dem ind i deres kristne rødder og forstå dem ud fra deres specifikke kontekst. 4

\section{Mariabilledet}

Når vi anskuer Bernhards fremstilling af
Maria som Kristi mor og hendes rolle som den diametrale modsætning til menneskehedens mor, Eva, så ser vi ham videregive en lang kristen tradition. Her slår den styrende dikotomi i opfattelsen af kvinder ( og mennesker?) igennem, nemlig tilstedeværelsen eller fraværet af kropslig renhed, symboliseret ved henholdsvis Maria og Eva.

Som tidligere antydet, udfoldes Bernhards mariologi kun i liturgiske tekster, nemlig i hans prædikener til mariahøjtiderne. Det vil sige, at hans mariologi først og fremmest er beregnet på pastoral-liturgisk brug, og at der ikke er nogen systematisk udarbejdet mariologi hos ham. Men Maria indtager trods alt en central stilling $\mathrm{i}$ hans teologiske antropologi: forståelsen af mennesket som skabt af Gud i sit billede, som falden fra sin bestemmelse og håbende på genskabelse til Guds billede og lighed i kraft af nådens/frelsens formidling. Som sådan er mariologien tæt forbundet med tilstedeværelsen eller fraværet af hellighed/renhed. Dette hænger sammen med, at tildelingen af nåde i katolsk frelseslære er styret af kausalitetsprincippet, dvs. jo tættere man som subjekt er et princip, jo større andel har man $\mathrm{i}$ dette princips virkninger. Hos de åndelige mennesker, de hellige og retfærdige, er der tale om en nådefylde efter modtagelighed og modtagelse: jo større kald, jo større nåde. Da Kristus er nådens princip, er de, der står ham nærmest de mest nådefulde. I dette system af hellige og retfærdige rangerer martyrer, apostle, helgener og engle højt. Men højest rangerer Maria, som i kraft af sit jomfruelige moderskab er placeret over såvel mennesker som engle. 5 Marias stilling som den højeste blandt skabninger er nemlig begrundet i den nådefylde, hun har modtaget som Guds jomfruelige mor. Kun Maria har kunnet forene de to faktorer: moderskab og bevarelse af den legemlige integritet. Hun besidder derved mere end de for frelsen kvalificerende dyder: kærlighed, jomfruelighed og ydmyghed, der af den patristiskmonastiske tradition fra oldkirken og frem 
forbindes med det paradisisk-englelige liv (jf. Pedersen 1986).

Bernhard kombinerer tre bibelsteder: Lukas 1,34; 1 Kor. 7,34 og 1 Mos. 3,15, for at underbygge at englen Gabriel kom til en ganske særlig kvinde, som var jomfru på legemet såvel som $\mathrm{i}$ ånden. Som modvægt til syndefaldet var Maria af Gud bestemt til og beredt på at knuse slangens hoved, og hun er således opfyldelsen af de gammeltestamentlige forjættelser. ${ }^{6}$ Da Maria var udset til at føde verdens frelser, som skulle ødelægge synden og døden, måtte hun være så ren, at hun ikke overførte verdens synd på ham. Derfor har Maria modtaget en overflod af helligelse allerede fra moders skød, og hun har i kraft af denne sin gudgivne syndfrihed levet op til det guddommelige ideal: det englelige liv på jorden. Det er vigtigt for Bernhards ideal om det frie, individuelle valg, som også hyldes i rekrutteringen af cisterciensermunke, at betone Marias frie tilslutning til sin forudbestemmelse. Han understreger, at Maria ud over at være helliget - frit har afgivet et jomfruløfte, hvorved hun har viet sit liv til jomfrustanden. Maria har behaget Gud ved frit at følge reglen for fuldkommenhed, nemlig "at leve ikke-kødeligt i kødet og at føre et engleligt liv på jorden." 7

Maria er med andre ord udvalgt til at genoprette syndefaldets virkninger, idet hver af Marias dyder er en kontrast til Evas laster. Især ydmygheden spiller en væsentlig rolle som fuldkommengørelse af jomfrueligheden, 8 for også Eva var jomfru. Ud over som livets mor at have genoprettet den synd og død, som Eva har forårsaget, har Maria også som en datter undskyldt Evas, menneskehedens mors synd (mater excusaretur per filiam) og derved tillige genoprettet Evas forhold til Faderen. Og en enkelt interessant formulering - "stilnet mandens klageråb over kvinden" (jfr. Adams udbrud, 1 Mos. 3,12).9 I In laud. 2,3 ekspliciterer Bernhard, hvorledes Evas værdighed genoprettes i Maria, idet de to er lænket til hinanden i den fælles skam, som er ophævet i én kvinde. Eva opfordres derfor til at gå til Maria, for datteren svarer for sin mor. Samme sted gør Bernhard sig til talsmand for, at manden (vir) er faldet via en kvinde, hvorfor han for balancens skyld må genrejses via en kvinde. ${ }^{10}$ Imidlertid fastholder han ikke denne opsplitning mellem kønnene, for Maria kaldes også i bredere forstand "forældrenes genskaberske, efterslægternes levendegørerske". Maria er da ikke reduceret til blot at have genoprettet kvindernes, men hele menneskehedens livsforhold.

Man møder altså uomtvisteligt i Bernhards pastoral-liturgiske mariasermoner den almindelige Eva-Maria-typologi. Men både i og uden for dette tekstkorpus, finder man samtidig, at Bernhard i grunden mest er optaget af kønnenes komplementaritet i henholdsvis faldet og frelsen. Afstemt med den tilsvarende og meget ældre Adam-Kristus-typologi (Rom. 5), understreger han til stadighed, at de to køn begge har del i faldet og derfor også begge må have del i genoprettelsen." "Ligesom den gamle Adam er blevet afløst af den ny Adam (Kristus), er Eva blevet overført til Maria”, hedder det samme sted. I en bredere forstand fokuserer Bernhard ikke på Adam versus Eva, men på menneskeheden versus Gud. Det er menneskeheden, der er faldet på grund af den af djevelen udsendte slanges gift, og altså ikke i snæver forstand på grund af Evas synd. ${ }^{2}$ Der spores allerede her en glidning bort fra den almindelige dikotomi mod den flertydighed, som er endnu mere udtalt i hans øvrige tekster, som jeg skal søge at illustrere i det følgende. ${ }^{13}$

\section{Kvindebillederne}

I Bernhards betydelige korrespondance findes 23 breve til kvinder. Størsteparten er skrevet til dronninger, hertuginder og fruer, mens mindsteparten er skrevet til nonner. De fleste er rådgivende eller irettesættende, enkelte er hengivne. Brevene kan ka- 
tegoriseres efter adressaten, om de er skrevet til verdslige kvinder eller til nonner, og især to træk skal fremhæves.

Det første træk, der skal fremhæves, er mønsteret i brevene til adelige og kongelige kvinder: de er ofte skrevet som en appel til kvindernes magt. De gifte kvinder anmodes om at bilægge stridigheder og bevæge deres ægtemænd til besindighed i forskellige sager. Eksempelvis beder Bernhard Adelaide, hertuginden af Lorraine, om at mane sin mand, hertugen, til besindighed $\mathrm{i}$ en krigsaffære. En anden Adelaide, dronning af Frankrig, anmoder han om at tage én af sine undersåtter, der uretfærdigt er eksileret, i forsvar. ${ }^{14}$

Det er bemærkelsesværdigt, at Bernhard ikke henvender sig til de magtfulde mænd selv, men netop til hustruerne. På den måde tillægges de jordiske dronninger og hertuginder samme midlerrolle som den himmelske dronning, Maria, der ligeledes kan gå i forbøn hos den magtfulde konge. Man ser her, hvordan det faktiske livs erfaringer og teologi/mariologi flyder over i hinanden. Kirken har indset, at den kan anvende kvinders indflydelse og overtalelseskraft politisk og vælger derfor at tolke den positivt på linie med den forbønsrolle, som Maria har. Brevene til dronninger og hertuginder viser, at Bernhard som kirken i øvrigt har erkendt, at de fromme, gifte kvinder kan udøve en positiv magt med det talte sprog, som tidligere vurderedes negativt. 15

Det andet træk, der skal fremhæves, er det styrende princip, som brevene til nonner er skrevet ud fra. De er nemlig alle præget af Bernhards teologiske antropologi og styret af hans monastiske teologi og liv. Det ses i den betonede distinktion mellem disse kvinders tidligere høje sociale status i det verdslige liv og deres nuværende lykke under Helligåndens ledelse. I et brev til den tidligere hertuginde af Bretagne, Ermengarde, ${ }^{16}$ fremhæver Bernhard det åndelige aspekt $\mathrm{i}$ hendes nye klosterliv i en række antiteser: hendes lykke stammer nu ikke fra kød og blod (nihil habet de carne et sanguine), men fra Helligånden; hun lever nu i ydmyghed frem for i storhed, i nedbøjethed fremfor rigdom, ligesom hun lever uden sin jordiske familie. Det er underforstået, at Ermengarde nu lever med sin sande familie (jf. Mark. 3,31-35; Luk. 2,49f.).

Skønt Bernhard her modstiller det kødelige, verdslige liv med det åndeligt styrede klosterliv, skal man være varsom med at tolke det som en dualisme. Bernhard omtaler ikke det materielle liv som i sig selv ondt eller syndigt. Kød og blod er ikke ondt, men det bør ikke være et mål i sig selv, fordi det er forfængeligt og forgængeligt. Som dets modsætning står det sande liv i kærlighedens ånd, under Guds ledelse, som det egentlige mål for livet. Kristus selv er billedet på, at vejen til den fuldkomne ånd går gennem kød og blod.

Ud fra samme præmis henvender Bernhard sig til jomfruen Sophia, der kaldes "en duelig kvinde af høj byrd", og en anden hellig jomfru, der mindes om den sande glædes proveniens, som er Skaberen, ikke skabningen. 17 Disse breve adskiller sig imidlertid fra de øvrige derved, at Bernhard i dem pointerer de to kvinders køn og svaghed. Begge nonner tiltales som svag kvinde (femina fragilis), og fremstilles altså med modsat fortegn af de magtfulde, verdslige kvinder.

Man kan undre sig over, at Bernhard sådan pointerer de to jomfruers køn og svaghed i stedet for blot at betone deres status som mennesker i relation til Gud. Det sidste ville nemlig være i overensstemmelse med hans teologiske antropologi, ifølge hvilken mennesket er kvalificeret gennem sin skabelse i Guds billede, sådan at de to køn befinder sig på samme ontologiske niveau i skabelsesordenen. Et svar kunne være, at vi her ser en antydning af, at selvom Bernhard anser de to køn for skabelsesmæssigt at være på samme niveau, så mener han ikke dette er tilfældet med hensyn til frelsesordenen. Men set i sin kontekst er svaret snarere, at Bernhard her taler 
til professionelle kristne, hvor hans sigte er tugtelsen i det åndelige liv, mens det med henvendelsen til de verdslige "herskerinder” drejer sig om at opnå storpolitiske resultater. Bernhard formulerer sig med andre ord forskelligt alt efter, hvilken adressat han henvender sig til, og hvilket sigte han har med sin henvendelse. Under alle omstændigheder må vi konstatere, at billedet transcenderer både éntydigheden og tvetydigheden, for Sophia kaldes samtidig en "duelig kvinde af høj byrd". I Bernhards tekst er der ingen kobling mellem kønnet og svagheden: Sophia er ikke svag, fordi hun er kvinde - hun er en svag kvinde, fordi hun er af høj byrd.

Når Bernhard taler om kvindelighed og svaghed, taler han ikke om kvinder som biologisk eller socialt køn, men han bruger udpræget termen "kvindelighed" som symbol eller billede, der kan appliceres på hvem som helst. ${ }^{18}$ Når Bernhard bruger termen "kvindelig(hed)" og kvindelige attributter, mener jeg derfor, at man kan tale om en tredje brug, en symbolsk og billedlig brug af termen, som er så flertydig og så krydset med andre billeder, at man ikke kan karakterisere den som en kategori men som en skala af betydningslag. Dette er tydeligt i hans Højsangssermoner, hvor han udtrykker sig i såvel kønsinklusive som kønstranscenderende metaforer. Det er især fremstillingen af Gud, der er kønsinklusiv, sådan at Gud betegnes som eksempelvis både far og mor, hvis karakteristika ubesværet krydses i Bernhards allegorier, så for eksempel Gud som far kan fremstå som højst "kvindelig" med sit milde skød. Mest kendt er dog nok hans kønstranscenderende billede af Kristus med de svulmende bryster og den moderlige mildhed. ${ }^{19}$ Men heller ikke den enkelte troende forbliver bundet til sit køn, for kønskategorierne bruges symbolsk om den enkeltes trosforhold, uafhængigt af det biologiske køn. Bernhard transcenderer ubesværet kønnet, så mænd udstyres med kvindelige attributter, ligesom kvinder bliver mænd. Således omtales kirken som helhed og de enkelte troende, mænd som kvinder, med den kvindelige metafor Kristi brud. Brudemetaforen underbygges yderligere ved, at bruden ligesom Kristus selv udstyres med frugtbare, runde bryster, der symboliserer kærlighedens tålmod og trøst. I forlængelse af denne metafor opfordres prælater og abbeder til at være åndelige mødre, der skal amme børnene i troen med den kristne læres og vejlednings mælk. ${ }^{20}$

Kvindelighed/kvindelige prædikater og attributter symboliserer mange ting. Vi har allerede set, at de symboliserer kærlighed, nåde, mildhed og trøst, men også svaghed. Med svagheden signaleres, at bruden ikke må identificeres med Gud. Bruden er ikke fuldkommen, bundet som hun stadig er af det kødelige og jordiske, og derfor er hun svag. Det er det jordisk og sanseligt bundne menneske, der beskrives som kvindelig og overfladisk, og som manglende mandighed, styrke og vedholdenhed. Modsat er mandighed symbol på fuldkommenhed, og for at nå dertil må mennesket gå vejen gennem selverkendelse ved at tage udgangspunkt i sine egne kødelige erfaringer. Mennesket skal erkende, at det er et menneske, og at det ikke selv er Gud. Bernhard anskueliggør dette bl.a. ved at applicere fortællingen om den syndige kvinde, der salver Jesus (Mt. 26), på sig selv. Når han søger trøst hos Kristus, er han selv denne syndige kvinde; og de, som bebrejder ham en selvoptagethed, må vide, at de dømmer overfladisk: "Dette er ikke en mand, som I tror, der kan klare store sager, men en kvinde." Han fortsætter, at dette er godt nok, for det er en nødvendig, ja en uomgængelig erfaring eller erkendelse at gøre. Først når man har bevæget sig fra kvindelighed til en moden mandighed, kan man yde større ting. Svagheden er fælles for alle mennesker, en kondition stammende fra de to køns konspiration ved syndefaldet. ${ }^{21}$ Det samme gxlder helligheden, at den er fælles, og at både mænd og kvinder må blive mandlige (viriliter), som vi kan se af Bernhards allegoriske selvbeskrivelse. ${ }^{22} \mathrm{Og}$ en- 
hver stereotyp kategorisering modvirkes af, at Gud, helligheden og fuldkommenheden selv, hele tiden beskrives på kryds og tværs af kønnene. Det guddommelige er også kvindeligt.

Vi ser i det hele taget hos cistercienserne og Bernhard en ny erfaringsbaseret epistemologi, hvor det materielle opvurderes, og kvinder ikke blot nedvurderes. Cistercienserne, som kun tillader voksenrekruttering, inddrager deres erfaringer fra livet uden for klosteret i den monastisk-teologiske oplæring, ligesom det konstante fysiske samvær, som klosterlivet tvinger dem til, bruges som et led i denne oplæring. Dette, at man altid gør alting sammen med andre, hvad enten man beder, arbejder, spiser eller sover, understreges som konstitutivt for opbygningen af både individet og fællesskabet. For cistercienserne er kroppen og det fysiske liv således ikke i sig selv et problem, for de er nødvendige for sjælens, det hele menneskes, forståelse af både verden i dens skabthed og sin egen begrænsning, og dens ansporelse til godhed.23 Dermed undermineres den gamle dikotomi mellem ånd/krop og afløses af en distinktion mellem kærligheden til det gode/kærligheden til det onde. ${ }^{24}$ Samtidig undermineres den traditionelle kønsdikotomi, hvor kvinder som biologisk køn xkvivaleres med det kødelige og onde, mens mænd som biologisk køn ækvivaleres med det åndelige og gode.

Man kan ikke konkludere, at Bernhard er fjende af hverken kroppen eller af kvinden. Hans syn på såvel kroppen som kvinden/mennesket er styret af hans teologiske antropologi og præget af den kompleksitet, diversitet og ambivalens som er karakteristisk for den gammeleuropxiske kirke. I sidste instans er det ligegyldigt, for kroppen og kønnet er ikke et mål i sig selv. Det menneskelige, fysiske liv er et redskab på vejen til det endelige mål: at blive Gud lig, som det var menneskets bestemmelse fra skabelsen (1 Mos. 1,27).
Men én ting er, hvordan mænd omtaler kvinder og det kvindelige, noget andet er, hvordan kvinderne opfatter og omtaler sig selv. Er forskellen så stor? Ikke nødvendigvis. For cisterciensernonnernes vedkommende er ligheden med Bernhard meget stor, fordi de bevæger sig i samme tradition og benytter sig af en lige så billedmættet sprogdragt. Den bærende idé, at mennesket er skabt gudbilledligt, går igen uanset forfatterens skøn. Men der er én stor forskel: Nonnerne afholder sig helt fra Eva-Mariatypologien. Antagelig fordi den vil være en spændetrøje for dem, og de selv i deres asketiske liv identificerer sig med jomfruernes jomfru, Maria. Men måske også fordi de ikke skriver tekster i prædikengenren. I det følgende vil jeg give tre eksempler på, hvordan nonner underminerer dikotomierne kvindelig/mandlig og krop/ånd.

\section{BEATRICE AF NAZARETH}

Som det første eksempel på, hvordan kvinder selv udtrykker sig, har jeg valgt at fremdrage én af de mest bemærkelsesværdige nonner fra 1200-tallet, Beatrice af Nazareth. Hun var uddannet i de store flamske skriptorier som illuminator og virkede desuden fra 1232 til sin død i 1268 som priorinde i det flamske kloster Nazareth, nær Tienen. Det, som især gør Beatrice enestående, er det forhold, at vi besidder tekster både af og om Beatrice. Skrevet af Beatrice selv findes bl.a. den længere traktat om de syv kærlighedsmåder: Seven manieren van beiliger minnen (Reypens og van Mierlo 1926; herefter SM); og om hende et vita skrevet ca. 10 år efter hendes død af en anonym munk: Vita Beatricis (Reypens 1968; herefter $V B)$.

Når man nærlæser og analyserer Beatrices tekster, slår det én, at hun aldrig omtaler sig selv som kvinde eller nonne. I stedet taler hun i tredje person om den kontemplatives erfaringer - enten upersonligt som "sjælen" (die siele) eller ved det personlige pronomen "hun" (sie), fordi "sjæl" er hun- 
køn. Det konstitutive træk i hendes teologi og religiøse erfaringer er - som hos Bernhard - den faste tro på menneskets skabelse til Guds billede og lighed. ${ }^{25}$ Hendes antropologi er altså som Bernhards teologisk, dvs. ses ud fra gudsforholdet, og også hun betoner til stadighed menneskets oprindelse fra Gud. Beatrice ser i overensstemmelse med sin cisterciensiske tradition skaberværket og mennesket som gudsskabt og således af oprindelig natur godt, ikke ondt.

Som titlen på hendes traktat om de syv måder for kærligheden signalerer, så er det direkte forhold til Gud, som er kærligheden per se, af afgørende betydning. Derfor er det mest prægnante billede, man făr af Beatrice $\mathrm{i}$ hendes egne tekster, da også billedet af den kontemplative nonne - den professionelle kristne - der ustandseligt arbejder med sin tro på den Gud, der har skabt mennesket, som har inkarneret sig for mennesket, og som nu helliggør mennesket. ${ }^{26}$ Det er, på linie med den kristne tradition fra Augustin, troen på den treenige Gud, der styrer hendes selvbillede. ${ }^{27}$ Dertil kommer, at hun som cistercienser er oplært i, at selverkendelse og gudserkendelse i kraft af skabelsen er kongruente størrelser. ${ }^{28}$ Billederne i fremstillingen viser tydeligt, at empiri (det erfarede liv), og teologi hører uløseligt sammen i dette univers. Teologi og trosforhold videregives ikke som en række teser og abstrakta, men videregivelsen sker allegorisk ved hjælp af billeder fra hverdagslivet. Således beskriver Beatrice kontemplationens forening med Gud via billedet af en husmoder (gelijc ere husvrouwen), der har god orden i sin husholdning. Trosarbejdet beskrives med billedet af haven, der skal passes, eller med et billede af det åndelige kloster, hvor fornuften er abbedissen, visdommen priorinden, klogskaben subpriorinden og så fremdeles. ${ }^{29}$ Endvidere bruger hun billeder fra naturen: sjælen er i kontemplationen som en fisk i vandet og en fugl i luften. ${ }^{30}$

Skønt Beatrice bruger billeder fra den umiddelbare hverdag, som læseren kan knytte til ved, så er hendes selvbillede ikke bundet til hendes $k ø n$, og hun interesser sig slet ikke for kønskategorier i bogstavelig forstand. Det kan der gives to gode grunde til. For det første den teologiske, at kønnet ikke spiller nogen rolle i frelsesmæssig henseende. For det andet den faktuelle grund, at Beatrice det meste af sit liv har levet i kvindefællesskaber, og det kan ikke udelukkes, at det kontemplative liv faktisk har forlenet kvinderne med en slags emancipation, som løftede dem ud af den traditionelle rolle som ensidigt kropslige fænomener. Men naturligvis betyder det ikke, at hun ikke er sig sit køn bevidst. Hun har trods alt som skriverske læst og kopieret mændenes teologiske traktater.

Det er derfor efter min mening signifikant, at Beatrice kun taler om skabelsen på grundlag af den første skabelsesberetning (1 Mos. 1,27), hvor Gud skaber “mennesket i sit billede,... "som mand og kvinde skabte han dem". Til gengxld afholder hun sig ganske fra at kommentere endsige nævne fortællingerne om Adam og Eva: 1) den anden skabelsesberetning (1 Mos. 2), hvor Eva skabes af Adams ribben som hans medhjælp; og 2) syndefaldsberetningen (1 Mos. 3), hvor Eva fristes af slangen og sammen med Adam drives ud af paradiset til de to køns forskellige og dog fælles skæbne som faldne. Det er sandsynligvis ikke tilfældigt, at Beatrice på denne måde undgår gængse bibeltekster, som af mandlige teologer - lige fra oldkirken - er blevet tolket som Guds sanktionering af kvinders underordningsforhold. Selvom Bernhard heller ikke anvender disse tekster på den gængse kvindeundertrykkende måde, så opererer han dog med dem. Derfor er det næppe betydningsløst, at hun udhæver den tekst, som kun kan tolkes som kønnenes, som menneskers, skabelses- og frelsesmæssige ligeordning.

I forlængelse heraf ser Beatrice ikke sig selv som en kvinde, der på grund af et bestemt køn skulle være svag og underordnet. Derimod ser hun sig selv som et menneske, 


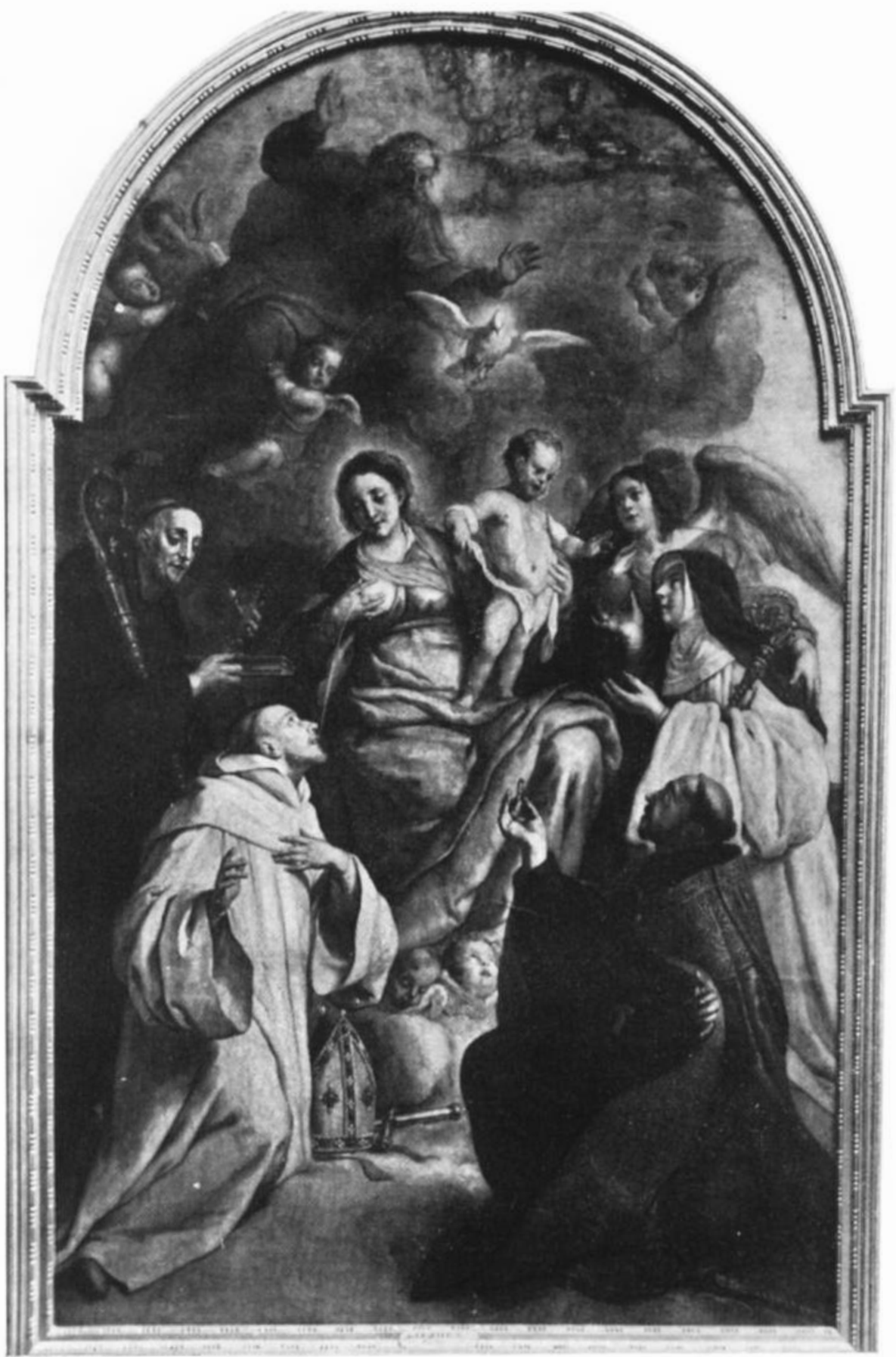

Beatrice af Nazareth (th. med abbedissestav) modtager forlovelsesringen af biskoppen, mens Bernhard af Clairvaux (knelende) modtager nadens malk af Marias svulmende bryst. Som bekreftelse på hendes lofte sender Gud sin Helligand. Abbedissestaven er en fejl, for Beatrice var kun priorinde.

Cryer, Gaspar de (1584-1669): alterstykke fra Nazarath kloster, nu Det kgl. Museum, Antwerpen. 
der i relation til Gud er underordnet og har sine svagheder. Det står stadig mere klart gennem en grundig nærlæsning og sammenligning af Beatrices tekst med biografens, at hun (sikkert bevidst) betoner det menneskelige og underbetoner det kvindelige og det kropslige, som så ofte sammenkobles - ikke mindst af Vita Beatricis s biograf. Beatrice er selv kun optaget af sit trosforhold og sin profession som kontemplativ nonne. Som de mange sprogbilleder viser, betyder det ikke, at hun tager afstand fra det fysisk-kropslige. Men det betyder, at hun er koncentreret om sit åndelige virke: i kontemplationen "med hjertets øjne" at beskue "det indre menneske".31 I kraft er sin profession er hun ganske naturligt optaget af kontemplationen, som er en erkendelsesmæssig, indre proces. Som det ofte betones: Beatrice ser ikke de guddommelige hemmeligheder med kroppens, men med sindets øjne. ${ }^{32}$ Som tidligere antydet, ligger der ikke heri nogen dikotomi $\mathrm{krop} / \mathrm{sj} x \mathrm{l}$ eller krop/ånd. Beatrice har lovet Herren både krop og sjæl som pant på sin vilje til at bevare troen på ham. ${ }^{33}$ Beatrice adopterer altså ikke på noget niveau en dikotomisk tankegang, hverken i form af kontrasten krop/ånd eller i form af kontrasten mandlig/kvindelig.

Det samme gxlder ikke den anonyme mandlige forfatter af hendes vita. For ham spiller kønnet og den krop, der knytter sig til kvindekønnet, så afgjort en rolle. Det er karakteristisk, at mens Beatrice selv fremstiller trosforholdet som et pågående åndeligt arbejde, så betoner biografen i malende gentagelser hendes trosforhold som så udpræget fysisk/kropsligt. Derfor har han i vitaet indfældet en række legemlige kampe, som Beatrice udkæmper i form af fristelser og sygdomme. Der lægges stor vægt på Beatrices kvindelige svaghed, som står som modvægt til hendes åndelige styrke. Det kommer helt eksplicit til udtryk, når man sammenligner Beatrices egen version af $\mathrm{Se}^{-}$ ven Manieren med biografens. Biografens kødeliggørelse af Beatrices åndelige reflek- sioner går igen i hele traktaten, og det indiceres allerede af det valgte subjekt. Hos Beatrice er subjektet upersonligt sjælen (die siele), hvilket kan appliceres generelt på enhver kontemplativ, mens subjektet hos biografen specifikt er Beatrice i en kontant, fysisk fremtoning.

Lad mig give et par eksempler på, hvordan biografen "inkarnerer" Beatrices åndelige refleksioner. ${ }^{34}$ Første eksempel: I den fjerde kærlighedsmåde er sjælen i Beatrices version så opfyldt af glæde og kærlighed, at det føles som om kroppen trækker sig bort. I biografens version fremstilles Beatrice som en "hellig kvinde", der i sin åndelige glæde ligger mat og syg i sengen, idet hun lider af paralyserende rysten og svækkelse. 35 Beatrices billedlige (som om) beskrivelse af en "kropsløshed" oversættes af biografen til fysisk svaghed i form af lammelse. Andet eksempel: I den femte kærlighedsmåde beskrives sjælen hos Beatrice som "legemligt styrket" (vromeger an dien lichame) og mere energisk i handling. Oplevelsen ses som en kærlighedsstorm og gengives med de fysiske tegn, der hører forelskelsen til: indre varmefølelse, blodets brusen og hjertebanken. Men biografen oversætter oplevelsen som en sindsyge, der har grebet Beatrice, og han betoner igen kropslig svaghed (imbecillitas corporalis) i en kontrast til hendes åndelige styrke. Atter "inkarneres" Beatrices billedlige fremstilling, og atter lykkes det ham at gøre hende sengeliggende. 36

Man ser hos Beatrice en balance mellem det fysiske og det åndelige, mens det kropslige hos biografen er så udpenslet, at det overskygger det egentlige budskab, nemlig Guds handling i mennesket. For Beatrice gxlder det om at videregive den kontemplative nonnes erfaringer med troslivet som en stadig proces, hvor Gud er den suveræne agens og mennesket den, der villigt må underlægge sig den guddommelige kærlighedsmagt. Men biografen, som skal fortælle en unik persons (en hellig kvindes) fantastiske historie, nedtoner/udelader Beatrices 
teologiske indslag, og iscenesætter og dramatiserer hendes stilfærdige refleksioner som et kropsligt martyrium. Biografen står langt mere fast i et dikotomisk univers end både Bernhard og Beatrice selv. Den senere reception af Vita Beatricis viser, hvordan den reflekterende kvinde bliver helt opslugt af dette kropslige drama, mens det åndelige drama - i form af hendes sobre teologiske refleksioner - forsvinder.

\section{Mechtild AF Hackeborn}

Den anden kvinde, der skal fremhæves er Mechtild af Hackeborn, som var lige så aktiv og professionel som Beatrice. Mechtild havde flere hverv, og foruden at være 1 . sangerske fungerede hun som lærerinde (magistra) ved klosteret Helfta, lige uden for Eisleben. Specielt for det tekstkorpus, vi har overleveret fra Helftanonnerne, er, at det angiveligt kun er skrevet of kvinder, nemlig - ud over Mechtild og hendes elev Gertrud af Helfta (se nedenfor) - andre (unavngivne) nonner fra klosteret. Her adskiller det sig fra hovedparten af periodens tekstmateriale om kvinder, der oftest som Vita Beatricis har en mandlig forfatter.

Mechtilds bog om den særlige nåde $L i$ ber specialis gratiae falder i syv dele, og omhandler alt fra kirkeårets fester over belæringer om det rette gudsforhold til beskrivelser af hendes sidste dage (Oudin 1877). Det er karakteristisk for Mechtild, at hun ligesom Beatrice udviser en bevidsthed om, hvilke bibeltekster man som kvinde bør undgå, og hvilke man til gengæld kan fremhæve og allegorisere.

Igen er udgangspunktet, at Gud i sin kærlighed har skabt menneskene til sit billede og sin lighed. Mechtilds teologi er ikke som Bernhards og Beatrices udformet som en tale om Gud, men som en samtale med Gud. Mechtild formår bogen igennem at fremstille sit trosforhold i et fornyende og kønsinklusivt sprog, hvor begge køn fuldt inddrages i det nære og kærlige familieforhold som et bærende billede. Det er et gen- nemgående tema, at Mechtild trøstes af Gud Kristus med påmindelsen om den guddommelige skabelse og frelse, hvor Gud er far i skabelsen, mor i frelsen, bror i delagtiggørelsen, og søster i fællesskabet. ${ }^{37}$ Kristi frelsesakt beskrives med billedet af en mild mor, der kærtegner barnet på sit skød, mens hun belærer det, og en hengivende far, der anerkender barnets bestræbelser. ${ }^{38}$ Kristus vil modtage ethvert menneske (homo), der vandrer i sandheden med ham, "som en mor modtager sit højtelskede barn med faderlige omfavnelser for aldrig mere at slippe det."39 Selvom Gud primært - i tråd med cisterciensertraditionen - fremstilles som kærlighed, pædagogisk skildret ved billedet af den kærlige far og især mor eller ved Guds hjerte som en smuk jomfru, ${ }^{40}$ så forfalder Mechtild ikke til romantiske skønmalerier. Realismen træder helt frem bl.a. i billedet af Kristus som den irettesættende mor, hvis barn har fjernet sig fra hende og er faldet. De mange familieportræetter af Gud bindes sammen af Guds allestedsnærvær: Gud er alt i alle, både far, herre, ægtemand og ven. ${ }^{41}$

Med sit kønsinklusive sprog, hvor hun stedse binder kønnene sammen ved at glide fra ét billede til et andet, fastholder $\mathrm{Me}$ chtild stædigt universaliteten i det kristne budskab. Både skabelsen, synden og frelsen omslutter alle. Det er, som om hun er klar over, at denne universalitet vil komme ud af balance med Eva-Maria-typologien, når hun udelukkende henviser til Adam-Kristus-typologien. Til forskel fra Bernhard nævner hun kun Adam (homo), ikke Eva, som billede på alle mennesker og deres tilbøjelighed til at synde og behov for frelse.

Skaberværket er et billede på Guds godhed. Både i naturen og i menneskets sanser kan Gud søges, hvorfor det materielle og kroppen så afgjort ikke er det åndeligt og teologisk reflekterende menneskes fjende. Det træder ganske særligt frem, hvor Mechtild lader Kristus gøre rede for de fem sansers betydning for gudserkendelsen: at se alt det smukke, at høre en dejlig melodi, 
at tale og læse, at lugte og føle - det viser altsammen hen på Guds milde og gode ånd. Gud har nemlig skabt alle disse gode ting, for at vi skal erkende hans skønhed og tiltrækkes af hans kærlighed. Igen hentes erfaringens moderbillede frem som forklaringsmodel: Gud er som en god familiemor (matrisfamilias), der ikke lader sit højtelskede barn arbejde alene. Ligeledes opfordres der til, at man foruden det åndelige arbejde tager vare på kroppen, for skønt den kun er en "ussel sæk", så er den nødvendig for gudserkendelsen, og hele kroppen tager del i lovprisningen af Gud, lige fra hovedet til fødderne.

Krop og ånd hører uløseligt sammen også hos Mechtild, og forbindelsen mellem de to understreges af Kristi inkarnation: "Hele min krop har også modtaget denne ære, så jeg kan være overalt i menneskeheden, som jeg er i guddommeligheden...".42 Atter ser vi et eksempel på, at de forenklede dikotomier kvindeligt/mandligt og kropsligt/åndeligt udmanøvreres og ophæves i den eneste gyldige kristne dikotomi: dikotomien Gud/skabning.

\section{Gertrud AF Helfta}

Endelig skal som den tredje cisterciensernonne fremhæves Gertrud af Helfta, som var Mechtilds elev fra hun som forældreløs, fem-årig pige, nærmest ud af det blå, kom til klosteret og blev adopteret af det. Hun var som de øvrige umådelig flittig og professionel, og menes at have assisteret Mechtild i dennes forskellige hverv. Hendes skrifter omfatter dels et værk om hendes åndelige øvelser, dels fem bøger (hvoraf hun selv har skrevet bog II) under titlen "Den guddommelige kærligheds herold" (Doyère et al. 1967ff).

Igen er gudbilledligheden konstitutiv for den teologi, som udfoldes. ${ }^{43}$ Men Gertrud, der er en yderst dygtig og intellektuel skarp kvinde, adskiller sig fra de øvrige nonner ved faktisk at pointere den menneskelige svaghed over for Guds åndelige styrke. ${ }^{44}$
Hvis Mechtild er fornyende i sit sprog, så er Gertrud det ikke mindre. Men hos hende er det ikke så meget i det kønsinklusive sprog som i den sublime drejning af kendte billeder og fortællinger fra bibelen, fornyelsen sker.

Det mest slående eksempel på dette er hendes indirekte anvendelse af 1 Mos. 2,23: Eva som skabes af Adams ribben. For Gertrud anvender ligesom Bernhard bibeludsagnet, at Eva er blevet ben af Adams ben og kød af hans kød, i en helt anden konstellation. Som Beatrice og Mechtild undgår Gertrud nogen direkte gengivelse af den anden skabelsesberetning (jf. ovenfor). I centrum står forkyndelsen af Kristi inkarnation, hvordan Kristus blev menneske, et menneske af ben og kød som Gertrud selv i sin skabthed er det. Gertrud tager som Bernhard udsagnet ud af dets oprindelige kontekst, og applicerer det genialt på Kristus, som i inkarnationen er blevet ben af hendes (Gertruds) ben, kød af hendes kød, for at frelse mennesker fra deres synd. 45

Gertrud taler nok om den menneskelige svaghed, men hun fremstiller så ganske afgjort ikke sig selv som en svag kvinde i kontrast til en mand, og man sporer heller ikke hos hende noget begreb om en særlig kvindelighed, der skulle være bundet til hendes køn. Til gengæld afslører Gertruds ordvalg, at forfatteren er en kvinde, dels når hun overfører bibelens billeder på sig selv, og dels når hun bruger sit eget liv som illustration af menneskets gudsforhold. Et par typiske eksempler: Et sted overfører Gertrud lignelsen om den fortabte søn (Luk. 15,11ff.) på sig selv, så hun er "den fortabte datter" (prodiga filia), der imødekommes med Guds faderlige barmhjertighed. Et andet sted bruger hun sin egen situation som forældreløs pige (orphana) i sin bøn til Gud, og et tredje sted ser hun sig selv som Guds adoptivdatter (deus qui in filiam adoptasti me). ${ }^{46}$

Mens det kønsinklusive sprog ikke er særlig udfoldet hos Gertrud, så spiller det kønstranscenderende sprog en ganske væs- 


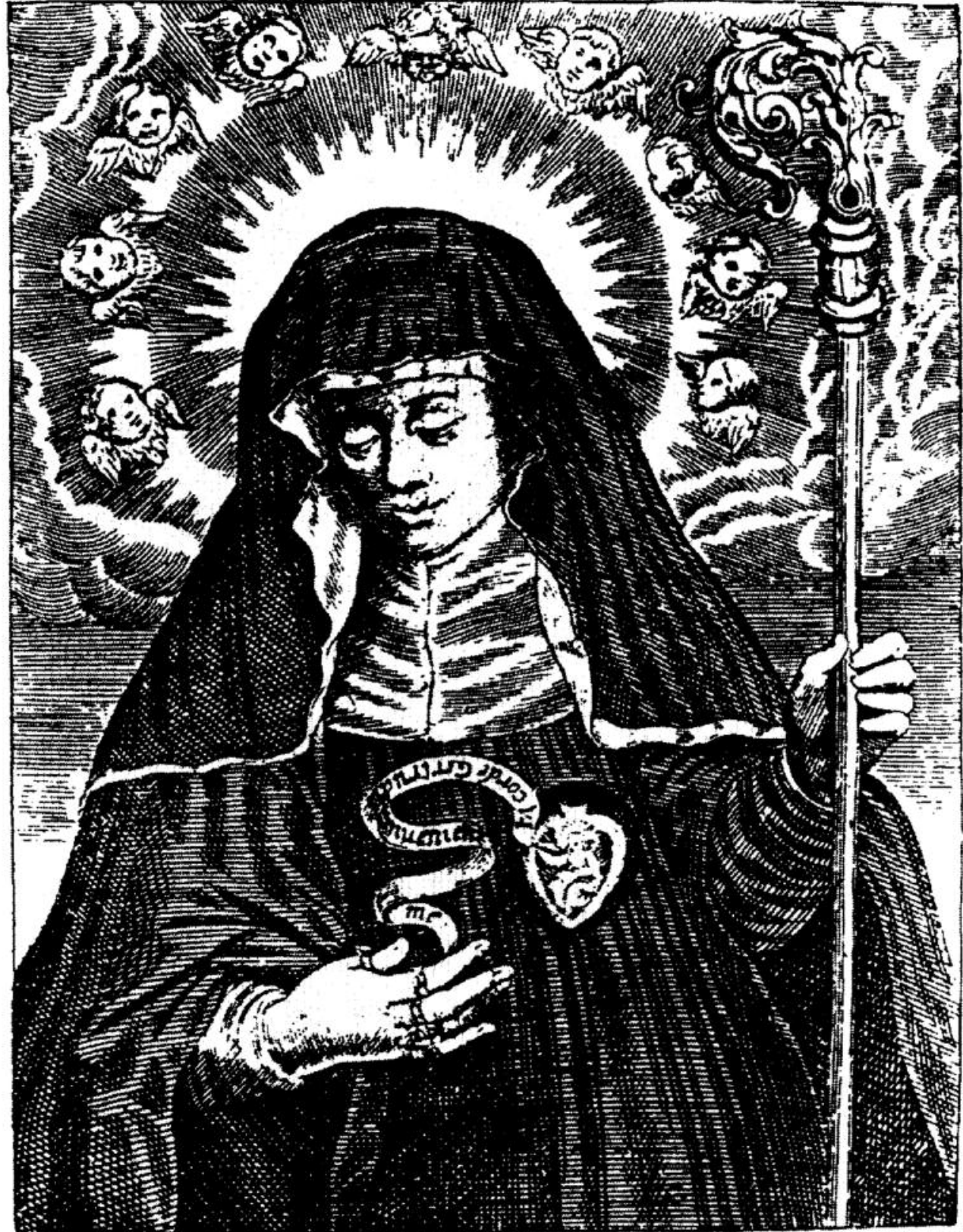

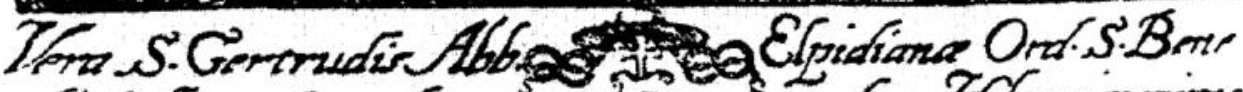

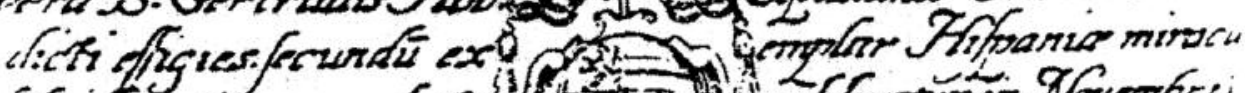

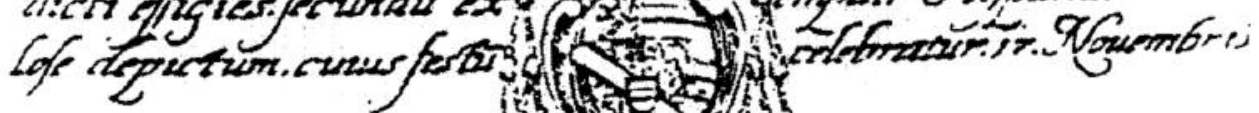
How

Gertrud af Helfta, den eneste kvinde i kirkehistorien, som har fäet tilnavnet "den store". Paul Seel: Kobberstik, ca. 1700. 
entlig rolle, både i skildringen af Guds omsorg og af Gertruds egen vej mod fuldkommenhed. Gud er, cisterciensertraditionen tro, både far og mor i sin kærlighed, ${ }^{47}$ hvilket igen afstemmes med en næsten endeløs række af billeder på Gud og den guddommelige kærlighed. Gertrud anråber Gud som blandt andet kærlighedsdronningernes dronning; og lige så interessant som tituleringen af Gud i denne anråbelse er, er anråbelsens formål: Gud skal hjælpe Gertrud med at tage virilitet på i sindet, så hun kan agere virilt og energisk $\mathrm{i}$ dyd (virtute). ${ }^{48} \mathrm{I}$ den forbindelse tyr Gertrud til det traditionelle symbolsprog: hun skal bevæges fra det svage køn (sexus fragilis) til kerlighedens art/køn (genus amoris) ved fornuftssjælens dyd og et virilt sind. Men igen går hun på tværs af en traditionel brug af termen "svagt køn", for den forbindes ikke med kvindelighed, men med ufuldkommenhed. Den ufuldkomne er af svagt køn, den fuldkomne af kærlighedens køn.

Hvor Gertrud omtaler sig selv som kvinde, sker det indirekte, som i selvbetegnelsen "en forældreløs pige uden mor" (orphana absque matre), og da står ikke mandligheden men menneskeligheden som kontrast. "Den elendigste og ondeste af alle" kalder hun sig selv i anråbelsen af Guds mildhed og i ønsket om at blive et menneske (homo) efter hans hjerte, og det et helt menneske af krop og sjæl. 49

Gertrud går, som både Bernhard, Beatrice og Mechtild imod de simple dikotomier, der deler verden op i krop/ånd og kvindeligt/mandligt.

\section{KONKLUSION}

Jeg har i denne artikel søgt at vise, at historien ikke sådan kan gives karakter, og at historiens forskellige aktører ikke så let lader sig kategorisere, såvel som de ikke altid benytter sig af forventede kategorier på forventede måder. Som Bernhard udtrykker det, kan man ikke nøjes med at se på overfladen, man må søge ind under den.
Med Bernhard af Clairvaux, Beatrice af Nazareth, Mechtild af Hackeborn og Gertrud af Helfta har jeg givet eksempler på en tradition, som ikke viderefører forståelsen af kvindeligt/mandligt og kropsligt/åndeligt som simple dikotomier eller dualismer. Både Bernhard og de tre nonner går på tværs af en kønsbundet kategorisering, og derved modvirkes også en angivelse af kvin$\mathrm{de} / \mathrm{mand}$ og krop/ånd som enten underordnet/overordnet eller ond/god. Kontrasten ligger i det enkelte menneske i form af det mere eller mindre hellige og fuldkomne. Kun Beatrices biograf går $\mathrm{i}$ den mere plumpe dualismes fælde, og forbinder - i sin bastante kødeliggørelse af Beatrices teologiske refleksioner - kvinden med kropslighed og svaghed.

I sin bog Holy Feast and Holy Fast konkluderer Caroline Bynum, at mænd og kvinder i middelalderen ud af det samme symbolunivers valgte forskellige symboler til at beskrive deres religiøse liv i modsætning til det verdslige. Mænd var, ifølge Bynum, langt mere tilbøjelige til at kontrastere kvindelighed med mandlighed, end kvinder. Bynum gør her en på mange måde både rigtig og væsentlig iagttagelse. Imidlertid mener jeg, vi skal være forsigtige med at skabe en for manifest, ny dikotomi mellem kvinders og mænds udtryksmåde. Vi må også tage højde for tekstgenrens betydning for forskelle i udtryksmåde, for en teksts genre og sigte er signifikant for dens udtryk. Vi ser Bernhard udtrykke sig forskelligt i breve og sermoner, med adressaten som en yderligere variabel. Eva-Maria-typologien optræder således hos ham ikke i tekster til kvinder som en revselse af kvinder, men hovedsageligt kun i de Mariasermoner, som han holdt for sine munke. Vi ser Beatrice og hendes biograf udtrykke sig forskelligt, især fordi vitagenrens fortælling om den hellige kvindes utrolige liv har et andet sigte end hendes teologiske refleksioner.

Under alle omstændigheder ser vi med 
de her nævnte fire eksempler, at kategoriseringer ikke altid er så ligetil at foretage. Mænd kan udtrykke sig i retning af en temmelig uelegant dualisme, sådan som Beatrices biograf gør det. Men der er også mænd, der ligesom kvinderne evner at underminere de for simple dualismer, idet de ved hjælp af en billedrig sprogdragt, hentet fra både klosteret og det omgivende samfund, ubesværet kan bevæge sig rundt i det store repertoire af kristne symboler. Derved undgår de dualismernes og kategoriseringernes forenklinger og fastlåsninger.

\section{Noter}

1. For de forskellige definitioner, se eks. Goetz 1986 og Davis 1957, 1988.

2. Bevægelsen var en udløber af benediktinerordenen, af munke som ønskede en stramning af klosterreglerne. Det første kloster blev oprettet af Robert af Molesme i Citeaux (deraf navnet cistercienser) i 1098 .

3. Eks. Fliche, A. og Martin, V. 1948, s. 107; og Ferrante 1975, s. 27-29, hvor Bernhard hastigt gøres til repræsentant for det syn, at kvinder er kødelige og sækulare sjæle uden virilitet, styrke og konstans.

4. Jf. Leclerqc 1982, s. 7, som i et opgør med Joan Ferrantes hurtige konklusion understreger, at sådanne generaliseringer kun undgås gennem en detaljeret læsning af alle Bernhards skrifter. I øvrigt havde Edith Russell (1953) et lignende opgør med A. Fliche og V. Martin (se note 5) i artiklen "Saint Bernard et les dames de son temps".

5. "Englen er stor, for den er Herrens tjener. Men Maria er større, for hun er hans mor. Jomfruens frugtbarhed er således den mest glansfulde ære,...”. In nativitatem Virginis Mariae, n.12, i Leclercq, Jean et al. (eds): Sancti Bernardi Opera (herefter $S B O) V$, Editiones Cisterciensis, Rom 1957ff, s. 283. (Alle oversættelser fra latin til dansk er mine). Mht. kausalitetsprincippet, se Robichaud 1957, s. 427 .

6. “...som forudskikket af fædrene, forjættet af profeterne ... var du af Gud udset til at knuse slangen...". In laud. Virginis Mariae, SBO IV, s. 42f. 7. "...in carne non carnaliter vivere et in terris angelicam ducere vitam." (In land. 3,7; SBO IV, s. 40. M.h.t. jomfruløftet, se In land. 2, 1; SBO IV, s. 21 .
8. "Sine humilitate autem (audeo dicere) nec virginitas Mariae placuisset." ( In land. 1,5, ibid. s. 43). 9. "...querela viri adversus feminam deinceps sopiretur.” (In Nat. V.M., n.6; SBO V, s. 278).

10. “...si vir cededit per feminam, iam non erigitur nisi per feminam." (SBO IV, s. 23).

11. Se bl.a. Dom.Oct.Ass., n.1., SBO V, s, 262:

“....adesset nostrae reparatione sexus uterque...".

12. Se eks. In die Pentecost. 2,3; SBO V, s. 167.

13. Jf. i øvrigt Muessig 1996, som på baggrund af en undersøgelse af Jacob af Vitrys sermoner fastslår en lignende glidning fra det stereotype til flertydigheden i kvindesynet. Der er en bred vifte af kvindelig hellighed, som viser, at det åndelige sprog ikke er låst fast på de to typer: Eva og Maria. 14. Ep. 120 (SBO VII, s. 300f) til Adelaide af Lorraine, som blev nonne i Tart mellem 1139 og 1142; Ep. 511 (SBO VIII, s. 470). Af samme slags er brevene til Melisande, dronning af Jerusalem (ep. 355) og til Mathilde, hertuginde af Bourgogne (ep. 121.

15. Jf. Farmer 1987, som gør rede for det paradigmeskifte, der finder sted i forhold til det talte sprog fra ca. år 1000 frem til 12.-13. århundrede, sammenfaldende med det europæiske samfunds større opmærksomhed på mennesket som et individ. 16. Ep. 117 (SBO VII, s. 298f.). Bernhard har skrevet to breve til Ermengarde (også ep. 116), som på hans foranledning er blevet nonne i benediktinerindeklosteret Jully, nær Dijon. Se nærmere herom i Pedersen 1989.

17. Ep. 113 og ep. 114 (SBO VII, s. 288ff.).

18. Her er jeg enig med Rubin 1992 og Partner 1993, som gør op med en kontant og entydig analytisk køns- og klassekategorisering i tolkningen af det religiøse sprog, der jo afspejler individet (sprogets subjekt) og den kontekst, det tales ind i. Til gengxld går Thomas Laqueur (1990) nok et skridt for vidt i sin Making Sex: Body and Gender from the Greeks to Freud, hvor han går imod den opfattelse, at det biologiske køn (sex) er primært og det sociale køn (gender) sekundært. Rækkefølgen er omvendt, påpeger han, idet han gør opmærksom på, at end ikke på det biologiske plan kan distinktionen mandlig/kvindelig siges at være forud for sproget. Man kan med andre ord ikke komme bag om sproget i en analyse af kønnet. Hvor sandt det end er, at kønskategoriseringer er konstruktioner, så behøver man ikke begå den biologistiske fejlslutning, at individet på grund af sit køn er determineret til at være på en bestemt måde, fordi man anerkender kønnenes biologi som reel, i den forstand at mænds og kvinders kroppe bl.a. forplantningsmæssigt har forskellige funktioner. Det forekommer mig totalt irrationelt at benægte, at vi er 
biologiske væsener før noget andet Og mon ikke vi var der, før sproget, ligesom vi fødes uden talesprog?

19. I Cant. 9,6 beskrives nådens formidling som nådens mælk, der flyder fra Kristi bryster og som er langt bedre end overordnedes reprimander: "Pinguedo gratiae, quae de tuis uberis fluit, efficacior mihi est ad spiritualem provectum quam mordax increpatio praelatorum."..."quia non modo internae dulcedinis lacte praesentes alis..." (SBO I, s. 46)

20. Se Cant. 9 og Cant. 10 (SBO I). Bynum var med sin bog Jesus as Mother (1982) med til at sætte spot på cisterciensernes og i særdeleshed Bernhards kønstranscenderende symbolsprog, som har lange kristne rødder tilbage til Irenæus i 2. årh.. Men forarbejdet var gjort af Cabassut, "Une dévotion peu connue: La dévotion à Jesus Notre Mère", i Revue d Ascetique et de Mystique, 25, 1949 , s. 234-45 og siden af Kari Børresen i forskellige artikler, bl.a. i Børresen 1978.

21. Cant. 12,8: "Quod est: 'Vos videtis in facie, et ideo secundum faciem iudicatis. Non est vir, ut putatis, qui possit mittere manum ad fortia, sed mulier...Bonum opus operatur in me....Si quando de muliere in virum, et virum perfectum, profecerit, poterit et in opus perfectionis assumi. "Vir" er etymologisk forbundet med "virtus" = mod, tapperhed, dyd og "virgo" = en jomfru. M.h.t. de to køns fælles svaghed, se Cant.72,7 og (Cant. 82,4 SBO II).

22. Jf. Frantzen 1993, som er nået til samme resultat på baggrund af en undersøgelse af angelsaksiske, hagiografiske tekster.

23. Se Cant. 5,1; Cant. 24,6. Jf. De diligendo Deo 11,30, hvor Bernhard pointerer det fysiske nærvær i kroppen og forbundetheden mellem krop og sjæl, og kroppen som den der i sidste instans leder mennesket til den legemlige opstandelse.

24. Se De deo diligendo 2,2; 6; 8,23-25; 15,39-40, hvor erkendelse af den konkrete eksistens fremhæves som det, der leder den enkelte til at elske Gud. Som Sharon Farmer udtrykker det: "A great speaker does not simply convey a disembodied message." (op.cit., s. 124).

25. Sjælens længsel er rettet mod gudbilledlighedens renhed, frihed og adel, som det udtrykkes i SM 1,10-18: “...ende te wesene in die puerheit. ende in die vriheit ende in die edelheit daer si in ghemaket es van haren sceppere na sijn beelde ende na sijn ghelikenesse, dat hart es te minnene...". 26S. M II,6-10: "Og ligesom en jomfru, der tjener sin Herre af stor kærlighed og uden belønning, er det også nok for hende, at hun må tjene ham, og at han mager det sådan, at hun tjener ham."
27. SM VII, 45-49: "I den ophøjede Treenighed er sjælens elskede hvilested og den bolig, som bringer hende glæde." Jf. VB II,94. Mennesket er ifølge Augustin et ufuldkomment billede på Treenigheden (imago Trinitatis) i sin sjæl/fornuft/ånd/forstand. Se eks. De Trinitate 7,12.

28. Beatrice beskriver i SM I,22-31, hvordan man skal arbejde hele livet for at nå lighed med kærligheden, for deri består fuldkommenheden.

29. VB II, 101-104.

30. SM VI, 20ff.

31. VB II,105-10: “...faciem interioris hominis in hiis,...inspicere...oculis cordis.”

32. VB I,55: “...non corporaliter sed intellectualibus, non carnis sed mentis oculis."

33. VB II,166: “...fidem quam se domino servare...illi totum quod potuit, id est corpus simul et animam,...obligavit.”

34. For en mere detaljeret redegørelse se Pedersen 1991 og 1994.

35. SM IV, 36-40: "Alse aldus har seluen gevuelt in die oueruloedichheit van waelheit...so wert hare geest altemale in minnen versinkende ende hore lichame hare ontsinkende...".

VB III, 254ff: “...languens et egrotans in lectulo decuberat...paraliticum tremorem incurreret...". 36. $S M V, 18-20 ; 42-46$; 77-80. Heroverfor VB III,255-56. Jf. Glente 1985, som har fundet samme tema i en række vitae over hellige kvinder; og Bynum 1987, som anser det for en misforståelse at betragte de mandlige teologers og biografers idéer om kvinder som kvinders selvbillede, s. 295.

37. $L S G I V, 50$ : "Cum quædam nimis tristaretur, compatiens devote orabat pro ea, quatenus pius Dominus per Spiritus Sancti consolationem ipsi dignaretur subvenire. Ad quam Dominus: 'Et cur turbaretur? Ego creavi eam mihi, et dedi me sibi ad omnia quæ requirit a me. Ego sibi pater in creatione; ego mater in redemptione; ego frater in regni divisione; ego soror in dulci sociatate."

38. LSG III,9: "...mater filio in sinu suo blanditur...paterni affectus suscipio."

39. LSG IV,7: “...velut mater amantissimum filium suum, inter paternos amplexus suscipiam perpetuo pausaturum." "Filius" kan oversættes med både "søn” og "barn”. Jeg har valgt "barn”, fordi Mechtild så tydeligt anslår den kønsinklusive tale med ordet "homo".

40. LSG II,16: “...amor meus erit mater tua; et sicut filii sugunt matres suas, sic et tu ab ea suges internam consolationem...". Mechtild omtales i denne samtale med Kristus som en unik datter. II,17: "Deinde vidit in corde Dei quasi virginem pulcherrimam habentem..."

41. LSG VII, 19 . 
42. LSG I, 19: "Toti etiam corpori meo hæc gloria donata est, ut sicut in divinitate ubique sum, ita etiam in humanitate..." Se også LSG III,44, hvor Kristus opfordrer Mechtild til at søge sig i sine fem sanser: "Quære me in quinque sensibus tuis..."; og LSG III, 49 og 48 .

43. Legatus II, 7.

44. Legatus II, 15: "Item gratia pietatis tuae illustrante intellectum meum, pluries revelasti, mihi qualiter anima manens in corpore humanae fragilitatis..."

45. Legatus II,5. Jf. Exercitia VI, v.180. Jf. Bernhard, Cant. 2,6, som også bruger udsagnet om Kristi inkarnation.

46. Se h.h.v. Exercitia IV,184; III,48 og V,510. 47. Eks. Exercitia VII,4: "pater misericordiarum"; v.26: "Tu omni indigenti semper tamquam mater subvenisti"; v. 299: "Tu tamquam mater perditum foves in gremio"; v.448: "tu materne et misericorditer omnium necessitas respicis"; og Legatus V, 25 , hvor vi ser et eksempel på, hvordan det mandlige (faderlige) og det kvindelige (moderlige krydses i en audition: "Ego te in exitu animae tuae faciam sub umbra paternitatis meae confoveri, sicut mater dilectum uteri sui in sinu veste sua contectum facit pausare, dum per horrida maria transnavigat".

48. Exercitia V,386ff. M.h.t. vir/viriliter/virtus se note 23 .

49. Exercitia III,53-59: "corpus et animam meam habet in manu sua. Ipse de me faciat quicquid suae pietati placuerit. $\mathrm{O}$ quis mihi tribuat, ut efficiar homo secundum cor eius, ut in me habeat desiderium suum iuxta optimum suum beneplacitum (Job $23,3) . ”$

\section{LITTERATUR}

\section{KILDER}

\section{Til Bernhard af Clairvaux:}

- Leclercq, Jean et al. (eds): Sancti Bernardi Opera IVIII, Editiones Cisterciensis, Rom 1957ff.

\section{Til Beatrice af Nazareth:}

- Seven manieren van heiliger minnen, i kritisk udg. af Reypens, L. og van Mierlo, J., De vlaamse Boekenhalle, Leuven 1926.

- Vita Beatricis, i kritisk udg. af Reypens, L., Antwerpen 1968.
Til Mechtild af Hackeborn:

- Oudin, H.: Revelationes Gertrudianae aec Mechtildiance II: Sanctoe Mechtildis: Liber specialis gratiae, Solesmensium O.S.B. Monachorum, Poitiers/Paris 1877. (I fransk oversættelse: Oudin, H.: Le livre de la Grace Spéciale. Révélation de Sainte Mechtilde, samme, Poiti ers/Paris 1878.)

\section{Til Gertrud af Helfta:}

- Gertrude d'Helfta: Auvres Spirituelles: tom.I. Les Exercises/Exercitia spiritualia, in Doyère, Pierre: Sources Chrétiennes 127, Les Éditions du Cerf, Paris 1967; tom.II-III. Le Héraut/Legatus divinae pietatis, in samme: SC 139, Paris 1968; og tom. IV-V., samme, in Clément, Jean Marie og Vrégille, Bernard de (eds.): SC 255 og 331, Paris 1978 og 1986.

\section{SEKUNDERLITTERATUR}

• Balling, J. (1986): Kristendommen. Poitikens Forlag, København

• Balling, J. (1991): "Middelalderbegrebets problematisering - et foredrag" in Fønix $1991 \mathrm{nr} .4$

- Barré, H. (1953): "Saint Bernard, Docteur Marial”, in Analecta s. Ordinis Cisterciensis IX, 3-4.

- Bynum, Caroline Walker (1982): Jesus as Mother. Studies in the High Middle Ages. University of California Press, Berkeley.

- Bynum, Caroline Walker (1987): Holy Feast and Holy Fast. The Religious Significance of Food to Medieval Women. University of California Press, Berkeley. - Børresen, Kari E. (1981): Subordination and Equivalence. The Nature and Role of Woman in Augustine and Thomas Aquinas. University Press of America, Washington D. C.

- Kari Børresen (1978):"'Male - female, a Critique of Traditional Christian Theology", in Temenos, 13-14

- Cabassut, A. (1949): "Une dévotion peu connue: La dévotion à Jesus Notre Mère", in Revue d'Ascetique et de Mystique, 25.

- Davis, R.H.C. (1957/1988): A History of Medieval Europe. Oxford.

- Farmer, Sharon (1987): "Softening the Hearts of Men: Women, Embodiment, and Persuasion in the Thirteenth Century", in Cooey, Paula M. et al. (eds.): Embodied Love. Sensuality and Relationship as Feminist Values. Harper \& Row, San Francisco 
- Ferrante, Joan (1975): Woman as Image in Medieval Literature from the Twelfth Century to Dante, New York.

- Fliche, A. og Martin, V. (1948): Histoire de lÈglise $I X$, Paris.

· Frantzen, Allen J. (1993): "When Women Aren't Enough", in Speculum vol. 68 nr.2, The Medieval Academy.

- Glente, Karen (1985): Hellige kvinder. Om kvindebillede og kvindebevidsthed i middelal deren, Middelaldercentret, København.

- Goetz, Hans Werner (1986): Leben im Mittelalter. München.

- Laqueur, Thomas (1990): Making Sex: Body and Gender from the Greeks to Freud. Cambridge Mass.. - Leclerqc, Jean (1982): La femme et les femmes dans lrom the Greeks to Freu. Téqui, Paris.

- Le Goff, Jaques (1985): L'imaginaire médiéval. Paris.

- Muessig, Carolyn (1996): "Paradigms of Sanctity for 13th-Century women”, in Kienzle, Mayne et al. (eds.): Models of Holiness in Medieval Sermons, Textes et Études du Moyen Age 5, Louvain-la Neuve. · Partner, Nancy F. (1993):”No sex, no Gender", in Speculum vol. $68 \mathrm{nr}$. 2, The Medieval Academy of America.

· Pedersen, Else Marie Wiberg (1986): “Marias jomfruelighed", in Pedersen, E.M.W. et al.(eds): Maria hver tid sit billede, Anis, København.

- Pedersen, E.M.W. (1989): "Ermengarde - en kvinde 'fanget' mellem 1100-tallets ridderideal og munkeideal”, in Dansk teologisk Tidsskrift, 1989/1.

- Pedersen, Else Marie Wiberg (1991): Gudsbillede Mariabillede - Kvindebillede. Om teologi og spiritualitet hos Beatrice af Nazareth. Aarhus Universitet. · Pedersen, Else Marie Wiberg (1994): "Vita Beatricis og Beatrices liv. Om tekstkorpus og kvindekrop," in Dansk teologisk Tidsskrift 3.

· Robichaud, A.J. 1957): "Mary, Dispensatrix of All Graces”, in Carol, Juniper B.(ed): Mariology II, Milwaukee.

- Rubin, Miri (1992): "The Eucharist and the Construction of Medieval Identities", in Aers, David (ed.), Culture and History 1350-1600. Wayne State University Press, Detroit

- Russell, Edith (1953): "Saint Bernard et les dames de son temps", in Bernard de Clairvaux, Paris

\section{SUMMARY}

Very often, the medieval view on "gender" and "body" is depicted as being either unequivocally negative or just equivocal. According to this simplistic picture, a number of medieval men and women have been portrayed as alternately extremely misogynist and extremely submissive and self-suppressing. With the examples of Bernard of Clairvaux, Beatrice of Nazareth, Mechtild of Hackeborn, and Gertrud of Helfta, this article tries to differentiate more subtly the perception of the concepts "woman/female" and "man/male" by pointing to their function as symbols within the Christian tradition. Furthermore, it is demonstrated that the view on body/soul is not an expression of simple dualism.

Lektor, lic.theol. Else Marie Wiberg Pedersen, Institut for Systematisk Teologi, Aarhus Universitet 